\title{
Egy új elfogadhatósági kritérium - a jelentős hátrány vizsgálata az Emberi Jogok Európai Bírósága gyakorlatában
}

\author{
Elfogadhatóság - jelentős hátrány - Emberi Jogok Európai Bírósága - emberi \\ jogok nemzetközi védelme - 14. kiegészítő jegyzőkönyv
}

1950-ben történt elfogadása óta az emberi jogok és alapvető szabadságok védelméről szóló római egyezményt (a továbbiakban: Emberi Jogok Európai Egyezménye, vagy Egyezmény) napjainkig 14 alkalommal módosították és egészítették ki. A kiegészítések elsősorban egy vagy több új, az Egyezményben eredetileg nem szereplő joggal bővítették a védelemben részesítendő értékek körét, míg a módosítások többnyire az Egyezmény által életre hívott (és 1998. november 1-jéig működött) Emberi Jogok Európai Bizottsága és Emberi Jogok Európai Bírósága eljárásrendjét változtatták meg. ${ }^{1} \mathrm{Az}$ 1994. május 11-én aláirásra megnyitott és 1998. november 1-jén hatályba lépett 11. kiegészítő jegyzőkönyv célja részben az Emberi Jogok Európai Bírósága eljárásának gyorsítása, részben pedig egy állandó, folyamatosan ülésező bírói fórum létrehozatala volt. A jegyzőkönyv hatálybalépése óta eltelt évek egyértelműen igazolták az új működési rend sikerességét és egyben szükségességét is. Amíg az Emberi Jogok Európai Bírósága 1958 (működésének megkezdése) és 1998 között összesen 837 ítéletet hozott² ${ }^{2}$ 2008-ra megszületett a Bíróság tízezredik ítélete is. ${ }^{3}$ Ráadásul a Bíróság sikeressége töretlennek tekinthető: 2011. augusztus 31-i állapot szerint a függőben levő ügyek száma elérte a 160200-at, mely szám különösen annak fényében tekinthető már-már aggasztónak, hogy 2011 első nyolc hónapjában 46750 kérelem érkezett a Bírósághoz, mely ez idő alatt 25260 ügyet tudott csak lezárni. ${ }^{4} \mathrm{Az}$ ügyek emelkedő számának további „,biztosítéka”, hogy az Európa Tanács 47 tagállamából több mint 800 millió potenciális természetes személy kérelmező fordulhat a Bírósághoz - és akkor még nem is vettük számításba a jogi személyiségü kérelmezőket, akik egyes, az Egyezményben foglalt jogok tekintetében ugyancsak

* Dr. Szemesi Sándor egyetemi adjunktus, Debreceni Egyetem Állam- és Jogtudományi Kar, Európa-jogi és Nemzetközi Jogi Tanszék, Debrecen, szemesi.sandor@law.unideb.hu.

1 A kiegészítések és módosítások fent idézett felosztása nem teljesen pontos: így például az élethez való jog tartalmát módosító 6 . és 13 . kiegészítő jegyzőkönyvek bízvást értékelhetőek adott esetben módosításként is.

2 European Court of Human Rights: 50 Years of Activity. http://www.echr.coe.int/NR/rdonlyres/ACD46A0F615A-48B9-89D6-8480AFCC29FD/0/FactsAndFigures_EN.pdf (2011. szeptember 25.) 5.

3 ECHR, Takhayeva és mások kontra Oroszország, 2008. szeptember 19-i ítélet (ügyszám: 23286/04).

4 European Court of Human Rights, 1/1-31/08/2011 Statistics, http://www.echr.coe.int/NR/rdonlyres/7B68F8652B15-4DFC-85E5-DEDD8C160AC1/0/Statistics_2011.pdf (2011. szeptember 25.) 1. 
tekinthetőek adott esetben áldozatnak. Ezen néhány statisztikai adat is jól mutatja, hogy miért vált égetően szükségessé az 1998-ban hatályba lépett eljárási rend további megreformálása.

Jelen tanulmány keretei között a legújabb eljárási reform egyetlen elemét, a jelentős hátrány mint elfogadhatósági ok vizsgálatát végzem el, részben az Emberi Jogok Európai Egyezménye 14. kiegészítő jegyzőkönyve és az ahhoz kapcsolódó magyarázó jelentés, részben pedig a 14 . kiegészítő jegyzőkönyv hatálybalépése óta eltelt immáron több mint egy év strasbourgi bírósági gyakorlata alapján.

\section{A ,jelentős hátrány" mint elfogadhatósági ok megjelenése}

Az Emberi Jogok Európai Egyezménye 14. kiegészítő jegyzőkönyve az Egyezmény 35. cikk (3) bekezdését oly módon módosította, hogy immáron a Bíróság az eléje terjesztett egyéni kérelmet akkor is elfogadhatatlannak nyilváníthatja, ha „a kérelmező nem szenvedett jelentős hátrányt, kivéve, ha az Egyezményben és az ahhoz kapcsolódó jegyzőkönyvekben meghatározott emberi jogok tiszteletben tartása a kérelem érdemének vizsgálatát teszi szükségessé, és azzal a feltétellel, hogy ezen az alapon egyetlen ügy sem utasitható el, amelyet hazai bíróság nem vizsgált meg megfelelően." ${ }^{5} \mathrm{Az}$ elfogadhatósági kritérium három elemből áll: egyfelől tartalmazza a jelentős hátrány vizsgálatát, másrészt rögzít két kivételt, melyek esetében jelentős hátrány hiányában is köteles a Bíróság érdemi eljárást lefolytatni: ha az Egyezményben foglalt emberi jogok tiszteletben tartása egyébként a kérelem érdemi vizsgálatát teszi szükségessé, illetőleg ha a kérelmet egy nemzeti bíróság sem vizsgálta meg korábban megfelelően. Ez utóbbi feltétel visszautal a strasbourgi bíróság és a nemzeti bíróságok viszonyára: az a tény ugyanis, hogy a Bíróság nem utasíthat el egy triviális kérelmet akkor, ha a kérelmező ugyan nem szenvedett jelentős hátrányt, de ügyét egy nemzeti bíróság nem vizsgálta meg alaposan, egyértelműen a szubszidiaritás elvét tükrözi, azaz biztosítja, hogy minden ügy bírói kivizsgálást nyerjen akár nemzeti, akár európai szinten. ${ }^{6}$

A jelentős hátrány, mint elfogadhatósági kritérium eljárási korlátja, hogy az új elfogadhatósági kritérium nem alkalmazható a jegyzőkönyv hatálybalépését megelőzően már elfogadhatóvá nyilvánított kérelmek tekintetében, továbbá a jegyzőkönyv hatálybalépését követő két évben csak a kamarák és a Nagykamara alkalmazhatja - egyesbíró és háromtagú tanács nem. ${ }^{7}$

Az elfogadhatósági kritériumok megváltoztatásának szükségességét 2001 szeptemberében az ún. értékelő bizottság vetette fel. A Bíróság akkori elnöke, a svájci Luzius Wildhaber által támogatott javaslat szerint a Bíróság a jövőben nem foglalkozna olyan kérelmekkel, melyek megítélése szerint nem vetnek fel lényeges kérdéseket. Ez a rendkívül bizonytalan feltétel felhatalmazta volna a Bíróságot arra, hogy már-már „európai alkotmánybíróságként” válogathasson az elé terjesztett kérelmek

5 Lásd a kiegészítő jegyzőkönyv 12. cikkét.

6 Explanatory Report to Protocol No. 14, 82.

7 Lásd a kiegészítő jegyzőkönyv 20. cikkét. 
közül, eltolva az ítélkezés hangsúlyát az iránymutató, jogvédelmet továbbfejlesztő esetjog javára az egyéni jogsérelmek orvoslása felöl. ${ }^{8}$ Az Európa Tanács keretében múködő Emberi Jogi Állandó Bizottság (Steering Committee for Human Rights) 2003. április 4-i jelentésében egyértelműen ezt a „de minimis non curat praetor” elvét támogatta, és némi modellszámításként úgy ítélte meg, hogy a jelentés elfogadását megelőző teljes hónapban, 2003 februárjában a Bíróság elé került 406 ügyből 19 (az ügyek mintegy $5 \%$-a) ezen új elfogadhatósági kritérium áldozatául esett volna. ${ }^{9} \mathrm{Az}$ Állandó Bizottság jelentése szerint ilyen jelentéktelen ügynek minősülnek az 500 eurónál kisebb értékü ügyek, a szomszédok közötti viták, vagy éppen a nyugdíj kézbesítésének helyével kapcsolatos ügyek adott esetben. ${ }^{10}$ Álláspontom szerint a jelentős hátránynak egy többé-kevésbé objektív értékhatárhoz kötése rendkívül veszélyes volna: elképzelhető, hogy egy kelet-európai nyugdíjas kérelmező számára 400 euró is rendkívül súlyos anyagi hátrányt jelent, miközben egy nyugat-európai vállalkozó számára 1000 euró sem feltétlenül jelent olyan összeget, melyet a havi kiadásai között különösebben „megérezne”. Érdekes ugyanakkor megjegyezni, hogy az Emberi Jogi Állandó Bizottság szerint az új elfogadhatósági kritérium nagyobb részben a tisztességes eljáráshoz való jogot (azon belül is az eljárások ésszerủ időn belül történő befejezésének követelményét) rögzítő 6 . cikkel, kisebb részben pedig (a diszkrimináció fokától függően) a hátrányos megkülönböztetés tilalmát kimondó 14. cikkel összefüggésben volna alkalmazható, legalábbis a modellszámítás alapjául szolgáló 2003. februári ügyek tekintetében. ${ }^{11} \mathrm{~A}$ hátrányos megkülönböztetés tilalma tekintetében azonban megjegyzést érdemel, hogy mindaddig, amíg a Bíróság esetjogában nem tesz egyértelmü különbséget a közvetlen és közvetett diszkrimináció esetei között, illetőleg nem különíti el egyértelműen a hátrányos megkülönböztetés alapjául szolgáló indokok vizsgálatát, addig ez utóbbi megjegyzés megítélésem szerint utópisztikusnak tünik. ${ }^{12}$

A jelentés csak mellékesen, egy lábjegyzet erejéig jegyzi meg, hogy néhány szakértő nem támogatta ezt a javaslatot, mert az az egyéni panaszjog lényegét korlátozná ${ }^{13} \mathrm{Ez}$ a fajta különbségtétel azért is különösen érdekes, mert maga a 14. kiegészítő jegyzőkönyv magyarázó jelentése is rámutat arra, hogy a 14. kiegészítő jegyzőkönyv megalkotásának egyik legfontosabb szempontja az volt, hogy a reform ne érintse az egyéni panaszjog lényegét. ${ }^{14}$

Hogyan fordulhat elő mégis, hogy ilyen jelentős a szakértői álláspontok közötti eltérés a tekintetben, hogy korlátozódik-e az egyéni panaszjog? A magyarázat az

8 Weller Mónika: Az európai emberi jogi rendszer reformja: egy új elfogadhatósági kritérium. Ami a tizennegyedik jegyzőkönyv magyarázó jelentéséből kimaradt, Acta Humana, 2004/4. 79.

9 Impact Assessment of Some Reform Proposals Under Consideration, CDDH-GDR (2003) 017, 9.

10 Guaranteeing the Long-term Effectiveness of the European Court of Human Rights, CDDH (2003) 006 final, http://www.coe.int/t/e/human_rights/cddh/3._committees/01.\%20steering\%20committee \%20for\%20human\%20rights\%20\%28cddh\%29/04.\%20working\%20documents/2003/2003_006final_en.asp\#TopOfPage (2011. szeptember 25.).

11 Impact Assessment of Some Reform Proposals Under Consideration, CDDH-GDR (2003) 017, Annex.

12 Erre vonatkozóan részletesen lásd: SzEMEsı Sándor: A diszkrimináció tilalma az Emberi Jogok Európai Bírósága gyakorlatában, Complex, Budapest, 2009.

13 L. a jelentés 3. lábjegyzetét.

14 Explanatory Report... 10-11. 
egyéni panaszjog megítélésében keresendő. A szakértők többsége ugyanis formális megközelítést alkalmazott, mely szerint az egyéni panaszjog azt jelenti, hogy „bárki, aki azt állítja magáról, hogy az Egyezményben védett jogok és szabadságok megsértésének áldozata, ügyét a Bíróság elé terjesztheti”, és hogy „minden egyéni kérelem elfogadhatóságát meg kell vizsgálni” ${ }^{15}$, ami kétséget kizáróan megvalósul az új elfogadhatósági kritérium beiktatásával is. A kisebbség (különösen Ausztria, Finnország és Magyarország szakértői) ezzel szemben úgy ítélték meg, hogy az egyéni panaszjog lényegét tekintve a jogorvoslathoz való jogot jelenti, melynek nem az a tartalma, hogy bárki kérelmet nyújthat be a Bírósághoz belátása szerint, hanem sokkal inkább az, hogy a kérelmeket érdemben is megvizsgálja a Bíróság - mely megközelítésben viszont nyilvánvalóan csorbul a panaszjog.

\section{Szükséges-e egy új elfogadhatósági kritérium?}

Az új elfogadhatósági kritérium megteremtésének indoka hivatalosan is az volt, hogy a Bíróság a korábbiaknál nagyobb mértékben tudjon szelektálni az eléje terjesztett ügyek közül, és azok közül az igazán fontos, elvi jellegü kérdésekre fordíthasson több időt - a kevésbé jelentős „tyúkperek” kárára. A 14. kiegészítő jegyzőkönyv magyarázó jelentése az új elfogadhatósági kritérium bevezetésének szükségességét mindenekelőtt azzal indokolta, hogy „a már létező elfogadhatósági kritériumok - amelyek értelmezésével kapcsolatban több évtizedes, ezért nehezen megváltoztatható esetjog jött létre - által biztosított rugalmasságnál még nagyobb fokú rugalmassággal" rendelkezzen a Bíróság. ${ }^{16}$ Megjegyzendő, hogy ezen hivatkozási alap elsődlegessége legalábbis megkérdőjelezhető: az Emberi Jogok Európai Bírósága ugyanis az ún. élő jog (living instrument) koncepció szellemében saját ítélkezési hatékonyságát azáltal is folyamatosan növeli, hogy az Egyezmény szövegétől némiképp elrugaszkodva, annak rendelkezéseit mindenkor napjaink jogi és társadalmi követelményeihez igazítja. ${ }^{17}$ A Bíróság ugyanakkor azt is kimondta, hogy az „élö jog koncepciót” nem csupán az Egyezményben található anyagi jogi rendelkezésekre kell alkalmazni, hanem az eljárásjogi előírásokra is, és ekként a Bíróság adott esetben meghaladhatja azt az értelmet, melyet az Egyezménynek az azt létrehozók eredeti szándékuk szerint tulajdonítottak. ${ }^{18} \mathrm{~A}$ fentiek alapján meglátásom szerint már elméleti síkon is kijelenthető, hogy nem volt feltétlenül szükség egy új elfogadhatósági kritérium megalkotására.

A 14. kiegészítő jegyzőkönyv magyarázó jelentése maga is rögzíti, hogy a „jelentős hátrány” („significant disadvantage”) fogalma értelmezésre szorul, így a Bíróság feladata lesz annak meghatározása, hogy mely hátrányt is tekint jelentősnek. ${ }^{19}$ Más szavakkal ez azt jelenti, hogy az új elfogadhatósági kritérium újabb esetjog kidolgo-

15 Explanatory Report... 10., 39.

16 Explanatory Report... 78.

17 Legutóbb lásd: ECHR, Stummer kontra Ausztria, 2011. július 7-i ítélet (ügyszám: 37452/02), 118.

18 ECHR, Loizidou kontra Törökország (pergátló kifogások), 1995. március 23-i ítélet (ügyszám: 15318/89), 71.

19 Explanatory Report... 80. 
zását igényli, ami rövid távon nemhogy nem csökkenti, de várhatóan még növeli is a Bíróság munkaterhét - már amennyiben a jelentős hátrány követelményét a Bíróság nem formálisan, hanem érdemben kívánja vizsgálni és alkalmazni. Weller Mónika még a 14. kiegészítő jegyzőkönyv hatálybalépése előtt ezzel egyezően fogalmazott: álláspontja szerint csak abban az esetben könnyítheti meg az új kritérium az elfogadhatatlanná nyilvánítást, ha a Bíróság indokolás nélkül és széles mérlegelési jogkörrel dönthet a kérelmek sorsáról. ${ }^{20}$ Megjegyzendő, hogy ilyen javaslat is készült a 14 . kiegészítő jegyzőkönyv előkészítése során: eszerint a Bíróság maga határozhatott volna arról, hogy elutasítja azon kérelmek vizsgálatát, melyek nem vetnek fel új, érdemi jogkérdéseket. ${ }^{21} \mathrm{~A}$ már idézett vizsgálat adataira támaszkodva, amíg a 2003. februárjában elemzett 406 ügy közül 19 (5\%) tartozott a jelentős hátrány hiányában elutasítandók közé, addig a 406 ügyböl 262 (64,5\%) lett volna elutasítható azon az alapon, hogy az nem vet fel új, érdemi jogkérdést („substantial issue”). ${ }^{22}$ Általában érdemi jogkérdést tartalmaz egy kérelem, ha az emberi jogok nemzetközi védelmének teljesen új vagy összetett megközelítését igényli; súlyos vagy szisztematikus jogsértés megtörténtét panaszolja; különös jelentőséggel bír a bepanaszolt államra tekintettel; olyan helyzetet sérelmez, melyben a nemzeti jogrendszer vagy a belső jogorvoslatok nem müködnek kielégítően; és végezetül, ha a demokratikus intézmények müködésére is kihatással van. ${ }^{23}$ Kétségtelen tény, hogy minél kedvezőbb egy reformjavaslat ügyteherre gyakorolt hatása (azaz minél több ügyet tud a Bíróság érdemi vizsgálat nélkül elfogadhatatlannak nyilvánítani), annál nagyobb az esélye annak, hogy teljesen át kell pozicionálni a Bíróság nemzetközi emberi jogi jogvédelmi mechanizmusban betöltött szerepét. Egyfelöl, megítélésem szerint egy ilyen jellegű módosítással az Emberi Jogok Európai Bírósága sokkal inkább válna egyfajta „nemzetközi alkotmánybírósággá”, mintsem az emberi jogok nemzetközi (európai) védelmének egyik legfőbb letéteményesévé. ${ }^{24}$ Másfelől, ez a változás alapjaiban alakítaná át az Emberi Jogok Európai Bírósága és különösen a Polgári és Politikai Jogok Nemzetközi Egyezségokmánya rendelkezéseinek hatékony érvényesülését felügyelő Emberi Jogi Bizottság (Human Rights Committee) viszonyát: könnyen elképzelhető, hogy a kérelmük biztos vizsgálatát igénylő panaszosok inkább az Emberi Jogi Bizottság eljárását fogják választani az Emberi Jogok Európai Bírósága helyett, még akkor is, ha a két testület eljárásában számtalan eltérés is figyelhető meg.

20 Weller: $i$. $m$., 81.

21 „empower the Court to decline to examine in detail applications raising no substantial issue under the Convention", Proposal of the Evaluation Group. Lásd: Impact Assessment of Some Reform Proposals Under Consideration, CDDH-GDR (2003) 017, 2.

22 Impact Assessment of Some Reform Proposals Under Consideration, CDDH-GDR (2003) 017, 9-10.

23 Impact Assessment of Some Reform Proposals Under Consideration, CDDH-GDR (2003) 017, Annex.

24 Hasonlóan: „Egyelőre nem jött még el az idő, hogy a strasbourgi bíróság európai alkotmánybírósággá váljon." A strasbourgi kormányképviseletet ellátó Höltzl Lipóttal Farkas Lilla és D. Tóth Balázs beszélget, Fundamentum, 2005/1. 38. 


\section{Az új elfogadhatósági kritérium a gyakorlatban}

Egyes ítéletek különvéleményeiben már 2010. június 1-jét megelőzően is utaltak arra a bírák, hogy a kérelmező nem szenvedett jelentős hátrányt, ekként beadványával érdemben nem is kellene foglalkozni: a Micallef-ügyben a Bíróságnak az eljárások ésszerú időn belüli lefolytatásának követelményét kellett vizsgálnia a máltai nemzeti bíróság egy olyan ügyével kapcsolatosan, melynek alapja két szomszéd jogvitája volt: egyikük a kimosott ruhákat a másikuk udvarára terítette ki száradni. ${ }^{25} \mathrm{Az}$ ügy egészen a strasbourgi bíróság Nagykamarájáig jutott el, ahol is a kisebbségben maradó Costa, Jungwiert, Kovler és Fura bírák azt a költőinek szánt kérdést tették fel, hogy a kérdéses ügy biztosan olyan súlyúnak tekinthető, mint amivel a Bíróságnak, pláne annak Nagykamarájának foglalkoznia kell? A négy bíró álláspontja szerint a kérelmet joggal való visszaélésként kellett volna kezelni, és ekként az Egyezmény kérelem elbírálásakor hatályos 35. cikk (3) bekezdése alapján érdemi vizsgálat nélkül elutasítani. ${ }^{26}$ Megjegyzendő, hogy hasonló hivatkozásra a bepanaszolt kormányok oldaláról is hozható példa. ${ }^{27}$ De facto a Bíróság már korábban is alkalmaz(hat)ta ezen elfogadhatósági kritériumot, például amikor joggal való visszaélésként értékelte és ekként elfogadhatatlannak nyilvánította egy 4500 eurós fizetéssel rendelkező német állampolgárnak az általa vásárolt magnéziumtabletta árából 7,99 euró vissza nem térítése miatt benyújtott panaszát, tekintettel (a pertárgyértéken túl) a Bíróság ügyterhére, valamint arra, hogy ez egy nemzetközi bíróság, melynek ennek megfelelő komolyságú ügyekkel kell foglalkoznia. ${ }^{28}$

Az új elfogadhatósági kritérium első alkalmazására már rögtön 2010. június 1-jén, a 14. kiegészítő jegyzőkönyv hatálybalépésének napján sor került, amikor is a Bíróság elutasította a kérelmezőnek egy román busztársasággal szemben 90 euró kártérítés megfizetése iránt zajló, és az eljárás feltételezett tisztességtelensége miatt a strasbourgi bírósághoz kerülő ügyét. ${ }^{29} \mathrm{~A}$ Bíróság (helyesen) már ebben az első ügyében is kitért arra, hogy önmagában a 90 eurós összeghatár még nem feltétlenül adna alapot a kérelem elutasítására, de amennyiben a követelt összeg nagyságát a kérelmező anyagi helyzetéhez viszonyítva vizsgáljuk, a kérelem elfogadhatatlanná nyilvánítása az egyetlen lehetséges helyes döntés. Ez azt is jelenti, hogy (szemben egyes korábbi törekvésekkel) nem határozható meg olyan összeghatár, amely alatt minden esetben kijelenthető, hogy a kérelmező nem szenvedett jelentős hátrányt, bár aligha valószínü, hogy elképzelhető Európában olyan élethelyzet, ahol a kevesebb mint 1 eurónak (22,50 rubel) megfelelő összegü illeték vissza nem térítése miatti eljárásban sikerülne a panaszosnak jelentős hátrányt valószínüsítenie. ${ }^{30} \mathrm{Az}$ elszenvedett kár mértékén túlmenően ugyanis minden esetben vizsgálni kell a kérelmező szub-

25 ECHR, Micallef kontra Málta, a Nagykamara 2009. október 15-i ítélete (ügyszám: 17056/06).

26 ECHR, Micallef kontra Málta, a Nagykamara 2009. október 15-i ítélete (ügyszám: 17056/06), Costa, Jungwiert, Kovler és Fura bírák részben eltérő véleménye, 1.

27 ECHR, Koumoutsea és mások kontra Görögország, 2003. március 6-i elfogadhatósági határozat (ügyszám: 56625/00).

28 ECHR, Bock kontra Németország, 2010. január 19-i elfogadhatósági határozat (ügyszám: 22051/07).

29 ECHR, lonescu kontra Románia, 2010. június 1-jei elfogadhatósági határozat (ügyszám: 36659/04).

30 ECHR, Korolev kontra Oroszország, 2010. július 1-jei elfogadhatósági határozat (ügyszám: 25551/05). 
jektív érzéseit is az őt ért sérelem tekintetében - hiszen az adott esetben olyan jellegű is lehet, mely pénzben nem feltétlenül fejezhető ki.

\section{Következtetések}

Jelen tanulmány kéziratának 2011. szeptember végi lezárásáig (azaz a 14. kiegészítő jegyzőkönyv hatálybalépésétől számított mintegy 15 hónap alatt) az Emberi Jogok Európai Bírósága összesen 8 ügyben döntött a kérelem azon az alapon történő el nem fogadhatóságáról, hogy a kérelmező nem szenvedett jelentős hátrányt, ami nyugodtan tekinthető elhanyagolható mértékünek. Jelen statisztika alapján bátran állítható, hogy az új elfogadhatósági kritérium ebben a formájában történő megalkotása nem érte el a kívánt hatást: a Bíróság ügyterhét érdemben nem csökkentette, sőt az elfogadhatóság vizsgálata során egy új szempontra is tekintettel kell lennie, teljesen feleslegesen. Érdekes megjegyezni ugyanakkor, hogy valamennyi, az új elfogadhatósági kritérium alkalmazását igénylő ügyben kelet-közép-európai államok ellen került a panasz benyújtásra (Magyarország elleni ügy ezek között nem szerepel, de például Csehország, Moldova, Oroszország vagy éppen Románia elleni igen), és az ügyek vagy a tisztességes eljáráshoz való jog, vagy pedig a tulajdonjog sérelmével kapcsolatosak. E tekintetben megállapítható tehát, hogy az Emberi Jogi Állandó Bizottság korábban idézett hatástanulmánya az új elfogadhatósági kritérium alkalmazási körében a tipikus ügytípust nagyjából helyesen ítélte meg (de például a hátrányos megkülönböztetés tilalmával összefüggésben egyetlen alkalommal sem vizsgálta a jelentős hátrány kérdését a Bíróság). Ugyanakkor az is leszögezhető, hogy az eredetileg sem túl ambiciózus, az ügyek mintegy $5 \%$-át említő becslés is egyértelműen túlzottnak bizonyult: a Bíróság által évente elfogadhatatlanná nyilvánított 35-40 ezer ügyhöz képest az említett 8 ügy százalékosan szinte nem is mérhető nagyságrendet jelent. És bár valószínűsíthető ugyan, hogy az elkövetkező években (2012. június 1-jétől), amikor már az egyesbíró és a háromtagú tanács is alkalmazhatja ezt az elfogadhatósági kritériumot, nőni fog az ezen okból elutasított kérelmek száma, ám az szinte kizártnak tekinthető, hogy ez a növekedés több nagyságrendet elérjen, és ekként érdemben csökkentse a Bíróság ügyterhét. Ha pedig ezt az arányt vetjük össze azokkal a korábban idézett esetekkel, mindenekelött a Bock-üggyel, ahol a Bíróság más okból ugyan, de elfogadhatatlanná nyilvánította azon beadványokat, melyek kérelmezője szemlátomást semmilyen jelentős hátrányt nem szenvedett, akkor kijelenthető, hogy ez az új elfogadhatósági kritérium várhatóan az elkövetkező években sem fogja gyökeresen átalakítani az Emberi Jogok Európai Bírósága esetjogát.

\section{Abstract}

Since its adoption in 1950, the Convention for the Protection of Human Rights and Fundamental Freedoms has established one of the best mechanism for the international protection of human rights. Because of the continuous increase of the European Court 
of Human Rights' workload, the modification of the Court's procedure was needed. During this reform, a new admissibility requirement is inserted in Article 35 of the Convention, which empowers the Court to declare inadmissible applications where the applicant has not suffered a significant disadvantage. This new admissibility criteria is applicable since 1 June 2010 (when Protocol No. 14. entered into force). The study examines the travaux preparatoires and the current text of the Protocol, and analyzes the case-law of the Court concerning this new criteria. 